\title{
Magnesium as Environmental Tracer for Karst Spring Baseflow/Overflow Assessment-A Case Study of the Pertuso Karst Spring (Latium Region, Italy)
}

\author{
Francesco Maria De Filippi (D), Silvia Iacurto D, Gerardo Grelle and Giuseppe Sappa *
}

Citation: De Filippi, F.M.; Iacurto, S.; Grelle, G.; Sappa, G. Magnesium as Environmental Tracer for Karst Spring Baseflow/Overflow Assessment-A Case Study of the Pertuso Karst Spring (Latium Region, Italy). Water 2021, 13, 93. https:// doi.org/10.3390/w13010093

Received: 27 November 2020 Accepted: 30 December 2020 Published: 4 January 2021

Publisher's Note: MDPI stays neutral with regard to jurisdictional clai$\mathrm{ms}$ in published maps and institutional affiliations.

Copyright: (C) 2021 by the authors. Licensee MDPI, Basel, Switzerland. This article is an open access article distributed under the terms and conditions of the Creative Commons Attribution (CC BY) license (https:// creativecommons.org/licenses/by/ $4.0 /)$.
Department of Civil, Building and Environmental Engineering (DICEA), Sapienza University of Rome, 00184 Rome, Italy; francescomaria.defilippi@uniroma1.it (F.M.D.F.); silvia.iacurto@uniroma1.it (S.I.); gerardo.grelle@uniroma1.it (G.G.)

* Correspondence: giuseppe.sappa@uniroma1.it; Tel.: +39-064-458-5010 or +39-345-280-8882

\begin{abstract}
Following a previous research carried out on the same site, this paper presents the update of the $\mathrm{Mg}^{2+}$ based method for the estimation of Pertuso Spring discharge, located in Central Italy. New collected data confirmed the validity of the proposed model and the conservative behaviour of $\mathrm{Mg}^{2+}$ for groundwater related to the Pertuso Spring aquifer. Further analysis allowed to obtain a local linear relationship between magnesium concentration and total spring discharge (including exploitation rate), regardless of the mixing model proposed with the Aniene River. As regards two samples which fall out of the linear relationship and could have been detected as "outliers", more in-depth data processing and sensitivity analyses revealed that the lowering in magnesium, at equal discharges, is determined by the appearance of the quick-flow component, less mineralized and related to storm events. Results showed that under specific conditions, related to the absence or presence of previous intense rainfall events, $\mathrm{Mg}^{2+}$ could be effectively a useful tracer for separating spring conduit flow (overflow) from diffuse flow (baseflow) within the karst aquifer.
\end{abstract}

Keywords: karst spring; aquifer; magnesium; environmental tracer; discharge; baseflow; overflow; mass balance model

\section{Introduction}

Many areas and cities all over the world are water-dependent on karst aquifers, due to the usual exploitation of their springs for water supply [1-3]. About one quarter of the global population is completely or partially dependent on drinking water stored in karst aquifers, which are now affected by climate change effects [2,4-7].

Their hydraulic characteristics are quite different from other aquifer types. A karst formation constitutes a three-dimensional hydrogeological basin, which involves both subsurface and surface hydraulic mechanisms [8-11].

Due to the dissolution process involving carbonate rocks, they present a complex conduit network within a low permeability fractured limestone volume. This process, called karstification on a large scale, leads to the development and increasing of conduit network size within the aquifer, where groundwater often drains very quickly to the karst spring outlet [12-14]. The high heterogeneity of the rock matrix implies high flow velocities (up to some $\mathrm{m} / \mathrm{s}$ ), and high discharge springs (up to some tens $\mathrm{of}^{3} / \mathrm{s}$ ) [15].

Hence, in karst aquifers, a Darcy law approach is usually not suitable [7] except for restricted ranges in the latest part of the recession limb where groundwater flow velocity is much lower due to the drainage from minor fissures and soil pores $[2,12,16]$.

Karst springs shows duality of discharge conditions: low and continuous discharge during dry periods when the drainage occurs through the matrix and high discharge with high temporal variability during intense recharge events, when groundwater flows prevalently through the conduit system. Nowadays, challenges faced by researchers 
generally deal with karst aquifer quantitative and qualitative issues: climate change impact on karst water resource availability, pollution and vulnerability assessment, anthropogenic pressures and sustainable water management [17-23].

Several approaches coupled hydrological and geochemical models to understand karst processes and subsurface hydrology, especially for karst conduit-systems. Sometimes these approaches are also useful to fill lack of data, correlating physical parameters (discharge) to the chemical or isotopic characteristics of the spring water [24-28]. In fact, karst springs discharge is not easily measurable by standard techniques or conventional instruments, even due to the extremely high variability of the parameter. Moreover, in case of extreme rainfall events, overflow springs are activated when the conduit carrying capacity is exceeded and depending on the conduit system geometry $[29,30]$. In this case, total discharge may be underestimated.

The difficulty in having karst spring discharge data and defining a single fixed crosssection, related both to the activation of different circulation mechanism of groundwater within the aquifer both to lack of in-depth monitoring, implied the increasing of artificial and environmental tracer application to assess karst spring discharges, different water sources and pathways, groundwater residence times and other hydrogeological processes [27,31-36].

For everything mentioned so far, differently from alluvial aquifers, karst aquifers have characteristics usually studied at a single point, which is the spring outlet. This is due to the different approach for assessing groundwater flowing. From a certain point of view, in the case of karst aquifer, the high spatial heterogeneity is accepted, in exchange for concentrating efforts on the continuous monitoring of karst spring, which is the only point that focuses all the information of the aquifer, including its uncertainties [11,13,37].

In some cases, thanks to the use of multiparametric probes, it is possible to acquire a huge number of data at any time scale. This allows recording any trend variation, even instantaneous, resulting from short-term and high intensity rainfall inputs. Some physical parameters, such as temperature (T) or electrical conductivity (EC), continuously monitored as natural tracers, can provide information on karst aquifer behaviour. The arrival of fresh rainwater at a karst spring is frequent after a storm and causes a changing in water temperature and often a decreasing in EC [37-42], whereas in other cases piston flow mechanisms or the expansion of the catchment feeding the spring may change this behaviour [42,43].

Other environmental tracers, as major ions and isotopes, which differently from the artificial ones do not require injection points, can be naturally detected sampling spring water at different times during the hydrological year and carrying out subsequent laboratory analyses $[27,31,32,40-46]$. For example, in karst setting with predominance of limestone reservoirs, the $\mathrm{Mg}^{2+} / \mathrm{Ca}^{2+}$ ratio is usually used to assess groundwater residence time, whereas in dolomitic geological settings the lower hydraulic conductivity of rocks, compared with that of limestone, favours the $\mathrm{Mg}^{2+}$ concentration increasing, as the waterrock interaction is longer.

Mass balance techniques are very frequent in hydrogeological applications, when there is a high difference in concentration compared to precipitation water and the specific component shows a nearly conservative behaviour in the process, implying that the tracer chemical variation is due only by the simple physical dilution process. For example, the mass balance approach is widely used to assess different water sources rates, separating base flow and quick/storm flow [47-51], even if a recent study showed that water concentrations in rivers changes due to new contributions related to the expansion of hydrologic connectivity during stormy events [52].

In some cases, hysteresis plots of $\mathrm{Mg}^{2+} / \mathrm{Ca}^{2+}$ ratios have been successfully used to describe karst spring discharge characteristics and to better distinguish conduit discharge (related to $\mathrm{Ca}$ ) from diffuse one (related to $\mathrm{Mg}$ ) [53]. Similar interesting plots have been presented for other parameters such as EC, Dissolved Oxygen and temperature, 
showing different phases and flow dynamics in the response of karst spring during the storm event [24].

The use of environmental tracer, as well as separating spring hydrographs, increased also in setting-up mixing models whose aim is to identify end members and assess relative contributions in wider and more complex systems, such as a stream water chemistry change due to the mixing with spring water (groundwater-surface water interaction). In karst settings, Magnesium and Calcium as tracers provided significant results in hydrogeological analysis of springs, as well as lakes and doline basins [33]. In particular, $\mathrm{Mg}^{2+}$ has already been used as a conservative tracer for spring discharge evaluation in several case studies, where mass balance technique was applied at the confluence of two streams $[54,55]$ or at the confluence of spring and stream water [47].

Following a previous research carried out on the same site [47], this paper presents the update of the $\mathrm{Mg}^{2+}$ based method for the estimation of Pertuso Spring discharge, located in Central Italy. Indeed, this tracer is useful due to its nearly conservative behaviour in karst, confirmed by the previous experiences and applications mentioned before. Mass balance technique has been applied to Pertuso Spring discharges using $\mathrm{Mg}^{2+}$ contents. Two different mixing models have been set up: the first one for the mixing system composed by Pertuso Spring groundwater and Aniene River surface water, the second one to separate spring conduit flow from diffuse flow within the aquifer. The novelty is represented by the latter one, which allowed identifying and estimating the rate of spring overflow as a deviation from the linear trend of baseflow.

\section{Geological and Hydrogeological Framework}

The study area is in the Latium Region (Central Italy), in the Upper Valley of the Aniene River, which is the second most important river that crosses the city of Rome [56]. The Pertuso Spring, together with Radica, Fonte del Forno and Acqua Santa Springs, is the main water feeding of the river, with high discharges (up to $4-5 \mathrm{~m}^{3} / \mathrm{s}$ ). The spring exploitation for drinking purpose is going to be enhanced by ACEA (the water supply agency of Rome), with a new water pipeline towards the southern Rome area. The water outlet is next to the boundary between the carbonate hydrogeological basin, mostly made of limestone, and less permeable geological formations (Figure 1).

The entire area is characterized by a highly fractured Cretaceous rocks, with a karst setting presenting karren, sinkholes, and other karst forms [57]. On the carbonate rocks, composed by the alternation of granular limestone and dolomite layers, there are some rather limited areas where Quaternary alluvial deposits, pudding stone, and clay outcrop [58,59].

Dissolution in karst conduits causes groundwater flowing very quickly towards the spring. Conduits network is complex, not allowing to identify underground water pathways throughout the limestone matrix. The rapid increasing of Pertuso Spring flow is frequent and usually related to stormy rainfall events, doubling, or even tripling the spring discharge within few tens of hours. Nevertheless, the aquifer shows a remarkable baseflow component, with a spring depletion volume of about $25 \mathrm{Mm}^{3} /$ year [20].

The hydrogeological basin of the spring extends for approx. $50 \mathrm{~km}^{2}$ and is mostly composed by limestone, whereas the hydrogeological basin of the upstream springs is characterized by the presence of only dolomitic rocks (Figure 2). 


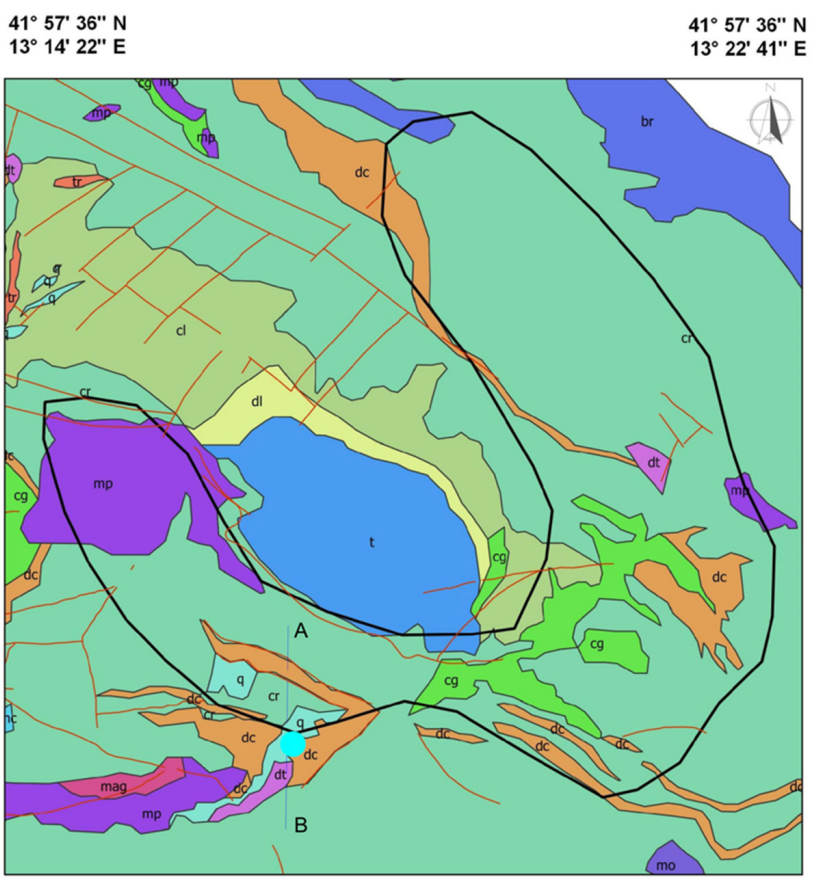

\section{Legend}

Pertuso Spring

$\square$ Hydrogeological Basin

Faults

Geology

dt - Debris flow

q - Ancient floods

mo - Moraine deposits

cg - Conglomerates

br - Breccia

mp - Pudding stone

mag - Clays and shales

mc - White and yellow granular limestone

cr - Limestone with dolomitic intercalations

dc - Compact limestone with dolomite

$\square \mathrm{cl}$ - Compact limestone and dolomitic limestone

$\square$ dl - Grey dolomite

t - White crystal dolomite

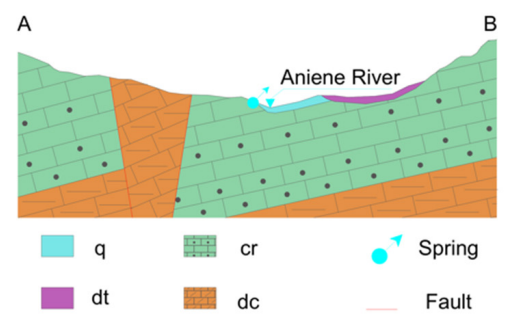

$41^{\circ} 51^{\prime} 41^{\prime \prime} \mathrm{N}$
$13^{\circ} 14^{\prime} 22^{\prime \prime} \mathrm{E}$

$41^{\circ} 51^{\prime} 41^{\prime \prime} \mathrm{N}$

$13^{\circ} 22^{\prime} 41^{\prime \prime} \mathrm{E}$

dt

티밀 $\mathrm{dc}$

Fault

Figure 1. Geological map of the study area and Pertuso Spring hydrogeological basin.

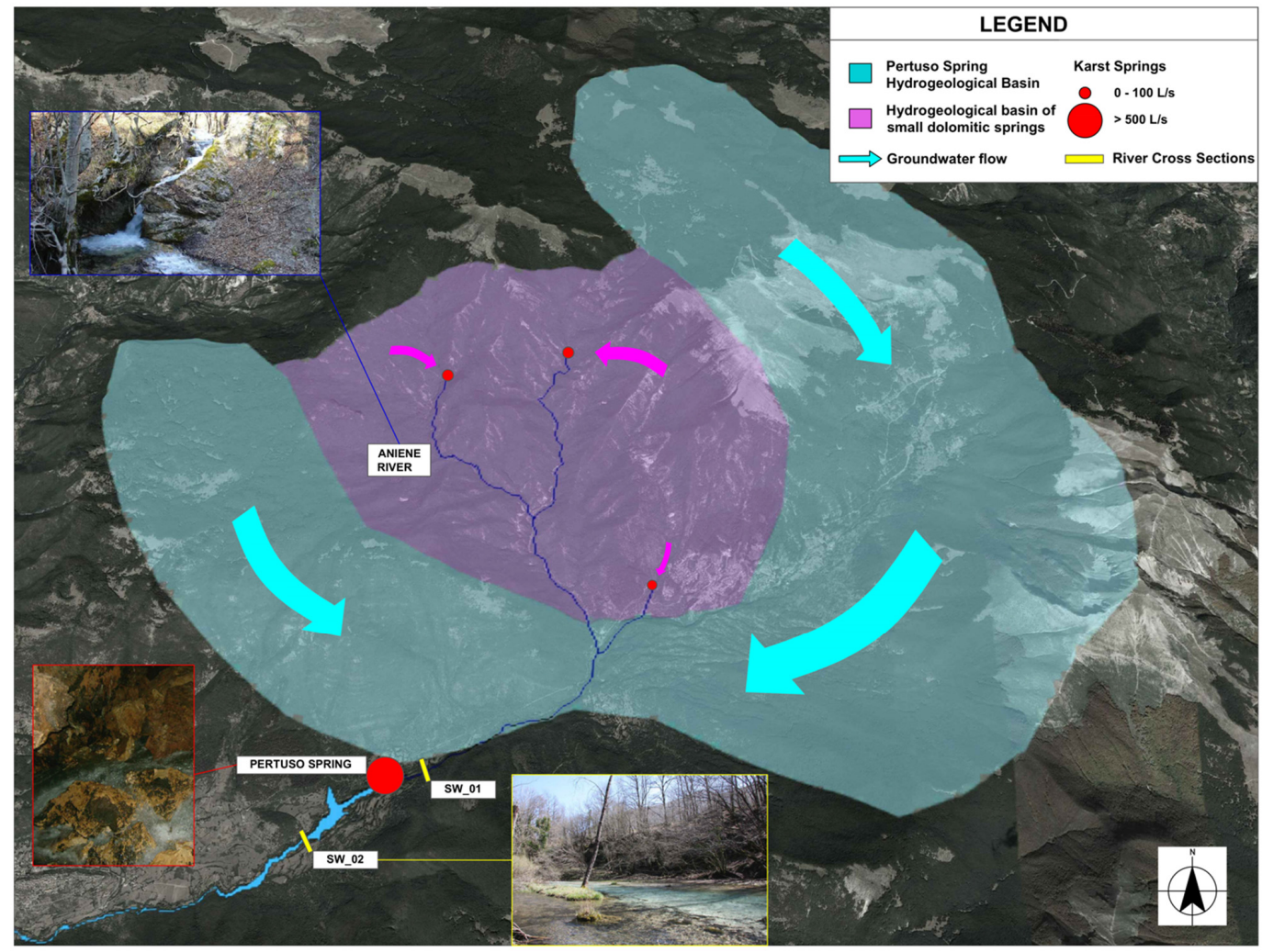

Figure 2. Hydrogeological basins of karst springs in the Upper Valley of Aniene River: in light blue the limestone reservoir feeding the Pertuso Spring, in purple the dolomitic one feeding upstream smaller springs. 


\section{Materials and Methods}

\subsection{Instrumentation and Measurements}

The activities, carried out during the first phase of the environmental monitoring plan for the spring catchment work, provided data about one spring (Pertuso) and two crosssections of the Aniene River (SW_01 and SW_01), from July 2014 to June 2019. One-time discharge measurements and water samples collection were carried out during winter and late spring months, due to the environmental monitoring plan, which initially took into account only two measurements per year for its first phase (spring and river minimum and maximum flow periods). The second phase of the plan, during which first catchment works are going to start, will consider monthly discharge measurements. This allows outlining a qualitative and quantitative framework of groundwater and surface water in the entire area during the ongoing project works. The cross sections, in which discharge measurements have been performed, are placed upstream (SW_01) and downstream (SW_02) the Pertuso Spring. Discharge assessment was coupled with geochemical analyses on water samples, collected with the measurements, for a total of 40 water samples analyzed.

Water temperature, electrical conductivity, $\mathrm{pH}$ values and dissolved oxygen were determined in field using HANNA HI9813-6 waterproof handheld meter together with water samples collection. In laboratory, water samples were filtered through cellulose filters $(0.45 \mu \mathrm{m})$, and their major and minor constituents were determined by ion chromatography (IC) by a 761 Professional IC Metrohm (reliability $\pm 2 \%$ ). Bicarbonate $\left(\mathrm{HCO}_{3}{ }^{-}\right)$was determined by titration with $0.1 \mathrm{~N} \mathrm{HCl}$ (reliability $\pm 2 \%$ ).

In addition, from January 2015 to March 2016, a multiparametric probe was installed in the spring containment tank, which directly interfaces with a data logger for real-time recording of hourly data referred to water temperature and electrical conductivity. Data recorded have been processed later, obtaining an average daily value for each parameter to compare with daily precipitation data referred to the termo-pluviometric station of Trevi nel Lazio, a small town located $2 \mathrm{~km}$ far from the spring (Table S1—see supplementary materials).

Precipitation data at Trevi nel Lazio station are free available on the website of Lazio Region, in the monitoring network section (http:/ /www.idrografico.regione.lazio.it/annali/ index.html).

Twelve (12) discharge measurements were carried out along the Aniene River, both in SW_01 and SW_02 by the application of traditional current-meter, as well as in the spring overflow cross section, in which now flows the difference between the total discharge and the exploited rate (about $0.3 \mathrm{~m}^{3} / \mathrm{s}$ ). According to U.S. Geological Survey (USGS) procedure and ISO, stream discharge has been calculated as the product of the cross-section area by the average stream flow velocity in that cross-section, obtained using a current-meter [60-62].

The main equipment needed to measure the stream flow velocity is a SEBA horizontal axis current-meter $\mathrm{F} 1$, having a propeller diameter of $80 \mathrm{~mm}$ which, combined with SEBA Z6 pulse counter, allows one to measure velocity between $0.025 \mathrm{~m} / \mathrm{s}$ and $10 \mathrm{~m} / \mathrm{s}$.

\subsection{Mass Balance Model}

The geochemical mass balance approach is used to assess mixing between water coming from different sources. In this paper, starting from $\mathrm{Mg}^{2+}$ contents $(\mathrm{C})$ and measured discharges of monitoring points $(Q)$, two different mass balance have been used:

- the first one related to the mixing system involving the Pertuso Spring groundwater (GW) and the Aniene River surface water (SW).

- the second related just to the groundwater of the aquifer feeding the spring, using typical rainfall concentration values to set up a mixing model and trying to separate conduit flow (overflow) from diffuse flow (baseflow).

As regards the first case, due to the absence of exchange between GW and SW in the river upstream and downstream the spring, the SW_02 discharge $\left(Q_{2}\right)$, is equal to the sum 
of the Pertuso Spring discharge $\left(Q_{P}\right)$ and the SW_01 discharge value $\left(Q_{1}\right)$, represented by Equation (1):

$$
Q_{2}=Q_{1}+Q_{P}
$$

The mass balance equation leads to the Equation (3):

$$
Q_{2} C_{2}=Q_{1} C_{1}+Q_{P} C_{P}
$$

Defining the parameter $n$ as the percentage of Pertuso Spring referred to the total discharge in the Aniene River at SW_02:

$$
n=\frac{Q_{P}}{Q_{2}}=\frac{C_{2}-C_{1}}{C_{P}-C_{1}}
$$

Rearranging Equations (2) and (3), Pertuso Spring discharge can be obtained by Equation (4):

$$
Q_{P}=Q_{1} \times \frac{n}{1-n}
$$

Thanks to the mass balance method, starting from the $\mathrm{Mg}^{2+}$ concentrations at monitoring points and the upstream discharge, we can directly evaluate the Pertuso Spring discharge calculating $n$.

With a similar approach, applied only to the total discharge of the spring, it is possible to distinguish the overflow component $\left(Q_{O F}\right)$ from the baseflow one $\left(Q_{B F}\right)$ :

$$
Q_{P} C_{P}=Q_{O F} C_{O F}+Q_{B F} C_{B F}
$$

Considering the spring system, Equation (5) is "activated" only when a storm event occurs. For the rest of the cases, when baseflow is predominant $C_{P}$ is equal to $C_{B F}$ due to the absence of the overflow component $\left(Q_{O F}=0\right)$.

\section{Monitoring Results}

\subsection{Hydrogeochemical Results}

Results of hydro-geochemical analyses carried out on GW and SW samples confirmed the carbonate facies of groundwater, where $\mathrm{Ca}^{2+}, \mathrm{Mg}^{2+}$ and $\mathrm{HCO}_{3}{ }^{-}$represent more than the $80 \%$ of the total constituents in water samples. They play a key-role in tracing groundwater and identifying different dissolution processes and water-rock interactions.

Surface water chemical characteristics, coming from the SW_01 monitoring point, are related to upstream springs (Ca-Mg- $\mathrm{HCO}_{3}$ facies), where dolomitic rocks outcrop and show a $\mathrm{Mg}^{2+}$ content, which is more than double, compared to the Pertuso Spring one (Ca- $\mathrm{HCO}_{3}$ facies).

Water samples, collected in SW_02, downstream of the confluence between Aniene River and Pertuso Spring presented chemical characteristics which are the result of the mixing (Table 1). 
Table 1. $\mathrm{Mg}^{2+}$ and $\mathrm{Ca}^{2+}$ ions concentration in monitoring point water samples.

\begin{tabular}{|c|c|c|c|c|c|c|}
\hline \multirow[b]{2}{*}{ Date } & \multicolumn{2}{|c|}{ SW_01 } & \multicolumn{2}{|c|}{ Pertuso Spring } & \multicolumn{2}{|c|}{ SW_02 } \\
\hline & $\begin{array}{c}\mathrm{Mg}^{2+} \\
(\mathrm{mg} / \mathrm{L})\end{array}$ & $\begin{array}{c}\mathrm{Ca}^{2+} \\
(\mathrm{mg} / \mathrm{L})\end{array}$ & $\begin{array}{c}\mathrm{Mg}^{2+} \\
(\mathrm{mg} / \mathrm{L})\end{array}$ & $\begin{array}{c}\mathrm{Ca}^{2+} \\
(\mathrm{mg} / \mathrm{L})\end{array}$ & $\begin{array}{c}\mathrm{Mg}^{2+} \\
(\mathrm{mg} / \mathrm{L})\end{array}$ & $\begin{array}{c}\mathrm{Ca}^{2+} \\
(\mathrm{mg} / \mathrm{L})\end{array}$ \\
\hline July-2014 & 23.6 & 53.4 & 9.77 & 48.9 & 12.8 & 51.3 \\
\hline November-2014 & n.d. & n.d. & 8.32 & 51 & n.d. & n.d. \\
\hline January-2015 & 25.2 & 57.8 & 9.9 & 53.3 & 13 & 55.6 \\
\hline February-2015 & n.d. & n.d. & 9.2 & 53.3 & n.d. & n.d. \\
\hline May-2015 & 24.6 & 53.9 & 9.3 & 49 & 12.2 & 51.4 \\
\hline December-2015 & 25.2 & 56 & 10.4 & 51.6 & 14.7 & 52.9 \\
\hline May-2016 & 25.2 & 56.6 & 9.53 & 53.2 & 12.5 & 54.6 \\
\hline November-2016 & 23.8 & 57.2 & 9.84 & 52.2 & 13.5 & 54.4 \\
\hline May-2017 & 24.2 & 54.7 & 10.4 & 49.6 & 13.9 & 52 \\
\hline June-2017 & 22.7 & 53.4 & 10.1 & 49.4 & 13.7 & 51.6 \\
\hline December-2017 & 25.2 & 56.2 & 10.7 & 52.1 & 15.9 & 54.9 \\
\hline May-2018 & 22.3 & 57.1 & 8.17 & 51.1 & 10.9 & 52.5 \\
\hline November-2018 & 25.1 & 58.6 & 7.43 & 58 & 10.8 & 59.1 \\
\hline June-2019 & 24.8 & 56.6 & 9.59 & 52 & 12.5 & 54.5 \\
\hline
\end{tabular}

\subsection{Pertuso Spring EC Real Time Monitoring Results}

Real-time recording of hourly data has been processed to obtain daily values of parameters as EC, T. Electrical conductivity is the most interesting, showing the spring depletion mechanism and highlighting the fast response after an intense rainfall event.

In Figure 3, a nine-month time window is represented as an example: the Pertuso Spring presents a double behavior in groundwater EC change during the hydrological year. The trend on an annual scale shows a slight fluctuating decrease and increase of EC values inversely proportional to the trend of spring flow. The minimum of EC is coincident with the seasonal maximum of spring discharge usually occurring in May.

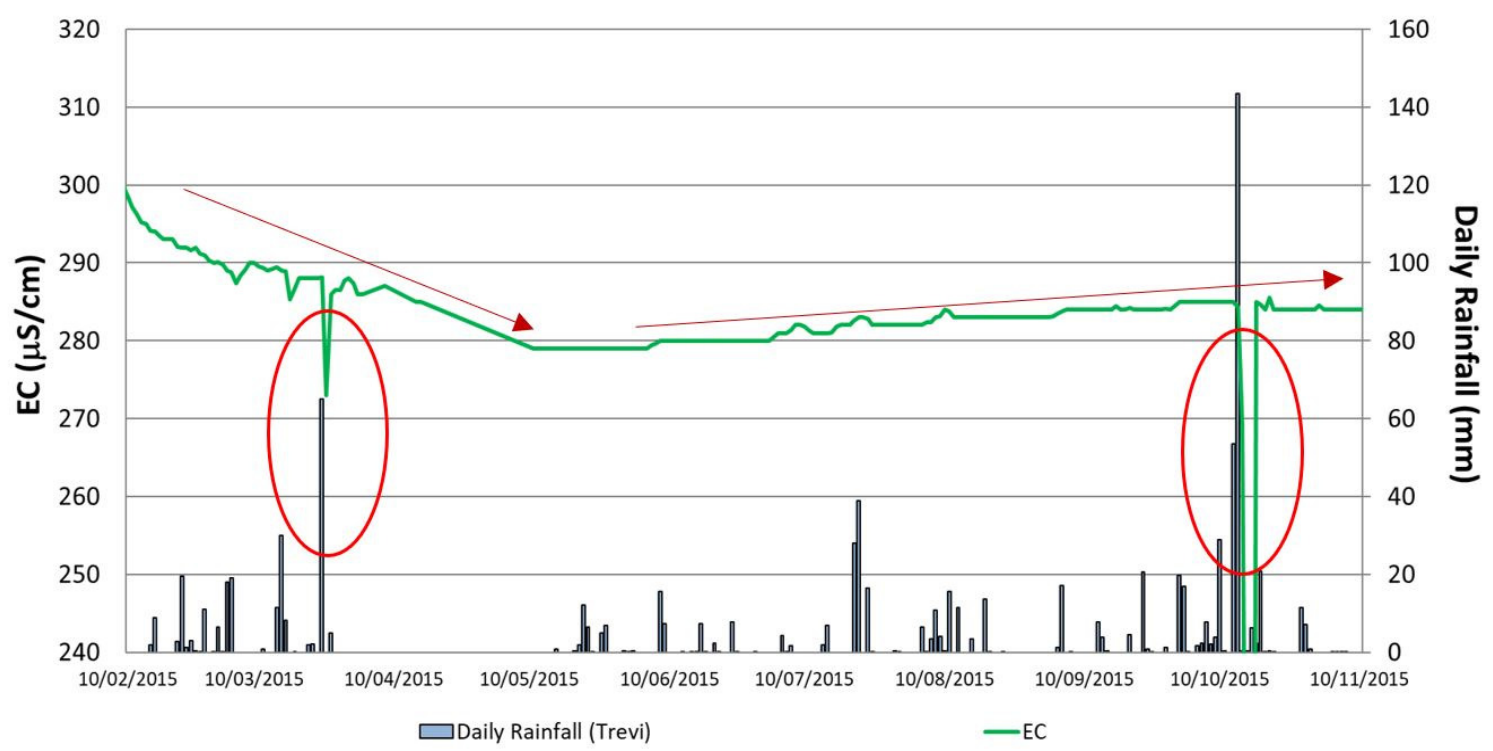

Figure 3. Continuous recording of spring water EC together with daily precipitation recorded at "Trevi nel Lazio" pluviometric station: Pertuso Spring seasonal trend and fast response to stormflow are highlighted with red arrows and circles, respectively.

The second trend refers to single intense rainfall events and shows the rapid spring response to the precipitation input with an instant drop of EC related to the arrival of storm water at the outlet point through the karst conduit system. 


\subsection{Discharge Measurements and Estimations}

For the Environmental Monitoring Plan goals, Aniene River and Pertuso Spring discharges have been measured during the period July 2014-June 2019, to study the annual ranging of the parameter before the start of the project works. Pertuso Spring discharges have been measured in a cross section upstream the confluence with the river. The total spring discharge $\left(Q_{T}\right)$ is the sum of this inflowing contribution into the river $\left(Q_{M}\right)$ with the exploited rate $\left(\mathrm{Q}_{\mathrm{EX}}\right)$ (Table 2).

Small differences between the measured value in SW_02 and the sum of SW_01 and the spring contributes are due to the intrinsic error of the instrumentation and to the error of the relief carried out by the operators, both increasing with discharge values (Table 2). Using the mass balance technique with $\mathrm{Mg}^{2+}$ contents, as explained in Section 4 , the evaluation of the parameter $n$ led to the estimation of spring inflowing discharges $\mathrm{Q}_{\mathrm{M}}$ (Table 3).

Discharge values of November 2014 and February 2015 were not obtained with the estimation method due to difficulty in accessing to the sampling points of the river (Tables 1 and 3). Results show the reliability of the estimation related to the mass balance method with limited errors, except for May 2016. Nevertheless, the R2 of the dataset is very high (0.899).

Table 2. Discharge values measured by traditional current-meter method at SW monitoring points $(\mathrm{Q})$, at Pertuso Spring cross section $\left(\mathrm{Q}_{\mathrm{M}}\right)$ and exploited rates $\left(\mathrm{Q}_{\mathrm{EX}}\right)$. The sum of $\mathrm{Q}_{\mathrm{M}}$ and $\mathrm{Q}_{\mathrm{EX}}$ is the total spring discharge $\mathrm{Q}_{\mathrm{T}}$.

\begin{tabular}{|c|c|c|c|c|c|}
\hline \multirow{2}{*}{ Date } & \multirow{2}{*}{$\begin{array}{c}\text { SW_01 } \\
Q\left(\mathrm{~m}^{3} / \mathrm{s}\right)\end{array}$} & \multicolumn{3}{|c|}{ Pertuso Spring } & \multirow{2}{*}{$\frac{\mathrm{SW} \_02}{\mathrm{Q}\left(\mathrm{m}^{3} / \mathrm{s}\right)}$} \\
\hline & & $Q_{M}\left(m^{3} / s\right)$ & $\mathrm{Q}_{\mathrm{EX}}\left(\mathrm{m}^{3} / \mathrm{s}\right)$ & $\mathrm{Q}_{\mathrm{T}}\left(\mathrm{m}^{3} / \mathrm{s}\right)$ & \\
\hline July-2014 & 0.54 & 1.91 & 0.36 & 2.27 & 2.45 \\
\hline November-2014 & 0.35 & 1.13 & 0.36 & 1.49 & 1.48 \\
\hline February-2015 & 0.50 & 1.74 & 0.36 & 2.10 & 2.24 \\
\hline May-2015 & 0.50 & 2.25 & 0.36 & 2.61 & 2.75 \\
\hline December-2015 & 0.28 & 0.67 & 0.36 & 1.03 & 0.94 \\
\hline May-2016 & 0.57 & 1.60 & 0.36 & 1.96 & 2.20 \\
\hline November-2016 & 0.36 & 0.73 & 0.36 & 1.09 & 1.13 \\
\hline May-2017 & 0.27 & 0.83 & 0.36 & 1.19 & 1.11 \\
\hline June-2017 & 0.20 & 0.67 & 0.55 & 1.22 & 0.87 \\
\hline December-2017 & 0.20 & 0.20 & 0.55 & 0.75 & 0.41 \\
\hline May-2018 & 0.69 & 2.98 & 0.36 & 3.34 & 3.64 \\
\hline November-2018 & 0.48 & 2.16 & 0.36 & 2.52 & 2.64 \\
\hline June-2019 & 0.39 & 1.62 & 0.36 & 1.98 & 2.02 \\
\hline
\end{tabular}

Table 3. Measured and estimated discharges of Pertuso Spring inflows to the Aniene River ( $\left.\mathrm{Q}_{\mathrm{M}}\right)$.

\begin{tabular}{cccc}
\hline \multirow{2}{*}{ Date } & $\boldsymbol{n}(-)$ & \multicolumn{2}{c}{ Pertuso Spring $\mathbf{Q}_{\mathbf{M}}$} \\
\cline { 3 - 4 } & & Measured & Estimated \\
\hline July-2014 & 0.78 & 1.91 & 1.92 \\
January-2015 & 0.80 & 1.51 & 1.61 \\
May-2015 & 0.81 & 2.25 & 2.16 \\
December-2015 & 0.71 & 0.67 & 0.68 \\
May-2016 & 0.81 & 1.60 & 2.44 \\
November-2016 & 0.74 & 0.73 & 1.00 \\
May-2017 & 0.75 & 0.83 & 0.79 \\
June-2017 & 0.71 & 0.67 & 0.53 \\
December-2017 & 0.64 & 0.20 & 0.36 \\
May-2018 & 0.81 & 2.98 & 2.88 \\
November-2018 & 0.81 & 2.16 & 2.04 \\
June-2019 & 0.81 & 1.62 & 1.65 \\
\hline
\end{tabular}




\section{Discussion}

Coupling results coming from geochemical analyses and spring discharge measurements, a high correlation between the spring hydrodynamic characteristics and some physical-chemical parameters, ranging during the hydrological year, is detected. Electrical conductivity was helpful to clearly mark the difference between diffuse flow and conduit flow regimes.

Starting from the previous experience in the same study area [47], $\mathrm{Mg}^{2+}$ has confirmed its nearly conservative behavior.

New data coming from collected water samples confirmed the linear trend with Pertuso Spring discharges in baseflow conditions, with no substantial lowering of the correlation degree $\left(R^{2}=0.85\right)$ (Figure 4$)$.

Dataset updating showed two water samples falling out of the trend line, related to November 2014 and 2018. The rest of dataset clearly defines a cluster, which falls near to the trend line. Deviation from the linear trend is comparable with errors related to chemical analyses $( \pm 2 \%)$ and discharge measurements $( \pm 5 \%)$ except for November 2014 and November 2018, as mentioned (Figure 5).

At first considered as outliers, these data actually show a different hydrodynamicsgeochemical mechanism of the aquifer, tracing the fast spring response to storm events.

The hypothesis made is that fast storm water circulation through conduit network does not allow the dissolution of dolomitic minerals in the intercalations within the limestone matrix, due to the slower kinetics that would require longer water-rock contact times.

Continuous monitoring showed that the duration of the spring fast response to the storm impulse ranges from 3 days to 5 days, depending on the magnitude of the event (Figure 3). In addition, the magnitude of the response is related to the previous baseflow conditions.

Hence, to verify this assumption, authors processed rainfall data daily recorded before the date of measurements. The sum of previous $72 \mathrm{~h}$ cumulative rainfall data pointed out that discharge measurements and water samplings in November 2014 and 2018 were carried out during spring overflow conditions (Table 4).

Table 4. 3-days and 5-days cumulative precipitation recorded at Trevi nel Lazio Rainfall Station before discharge measurements. The station is the nearest to the Pertuso Spring. Squared rows highlight intense rainfall events.

\begin{tabular}{ccc}
\hline \multirow{2}{*}{ Date } & \multicolumn{2}{c}{ Trevi Nel Lazio Rainfall Station } \\
\cline { 2 - 3 } & $\mathbf{P}_{\text {3-DAYS }}(\mathbf{m m})$ & $\mathbf{P}_{\text {5-DAYS }}(\mathbf{m m})$ \\
\hline 22-July-2014 & 17.6 & 17.6 \\
20-November-2014 & 40.8 & 76.4 \\
28-January-2015 & 0 & 7.8 \\
28-February-2015 & 23.8 & 26.6 \\
12-May-2015 & 0 & 0 \\
03-December-2015 & 0 & 0 \\
19-May-2016 & 24.8 & 68.6 \\
24-November-2016 & 0.4 & 31.8 \\
23-May-2017 & 0 & 24.8 \\
24-June-2017 & 0.2 & 0.2 \\
04-December-2017 & 5.4 & 5.4 \\
28-May-2018 & 21 & 31.8 \\
28-November-2018 & 91.2 & 110.2 \\
06-June-2019 & 8.4 & 39.2 \\
\hline
\end{tabular}




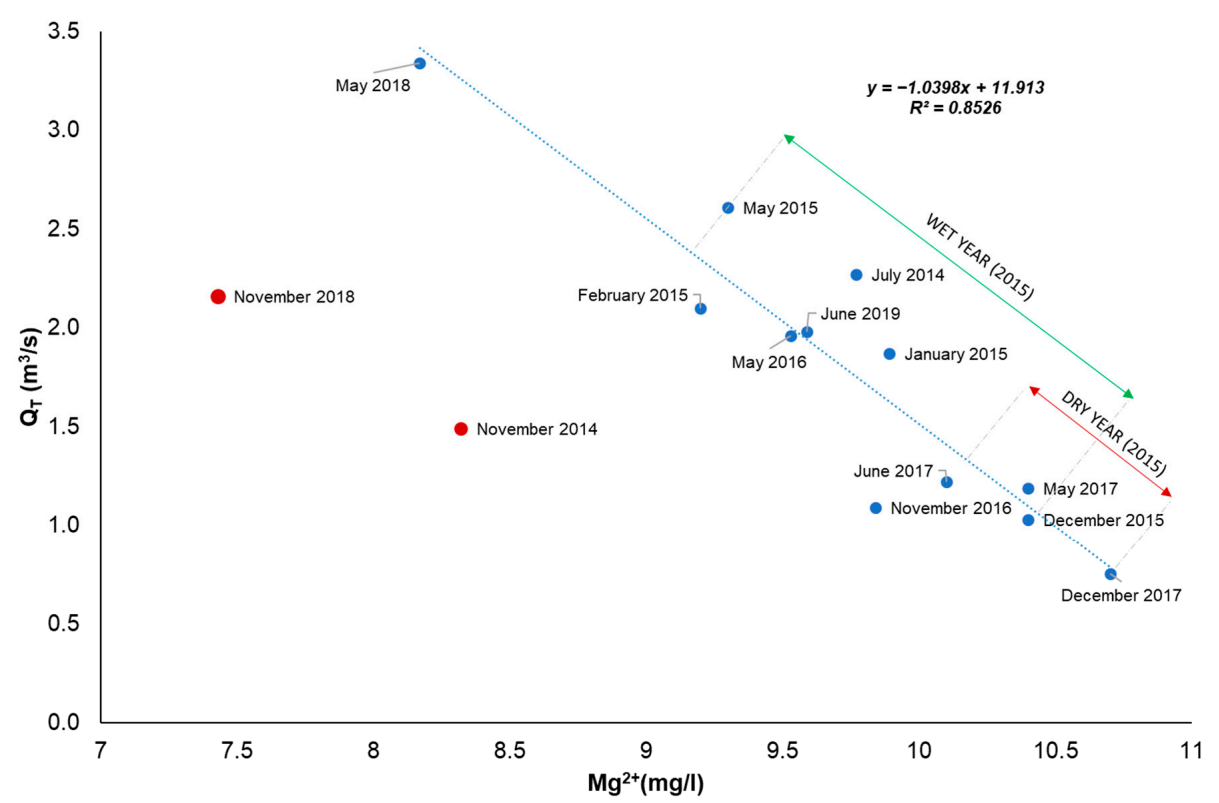

Figure 4. $\mathrm{Mg}^{2+}$ vs. Pertuso Spring total monthly discharges scatter plot. The double red arrow highlights a very important drought event occurring in 2017.

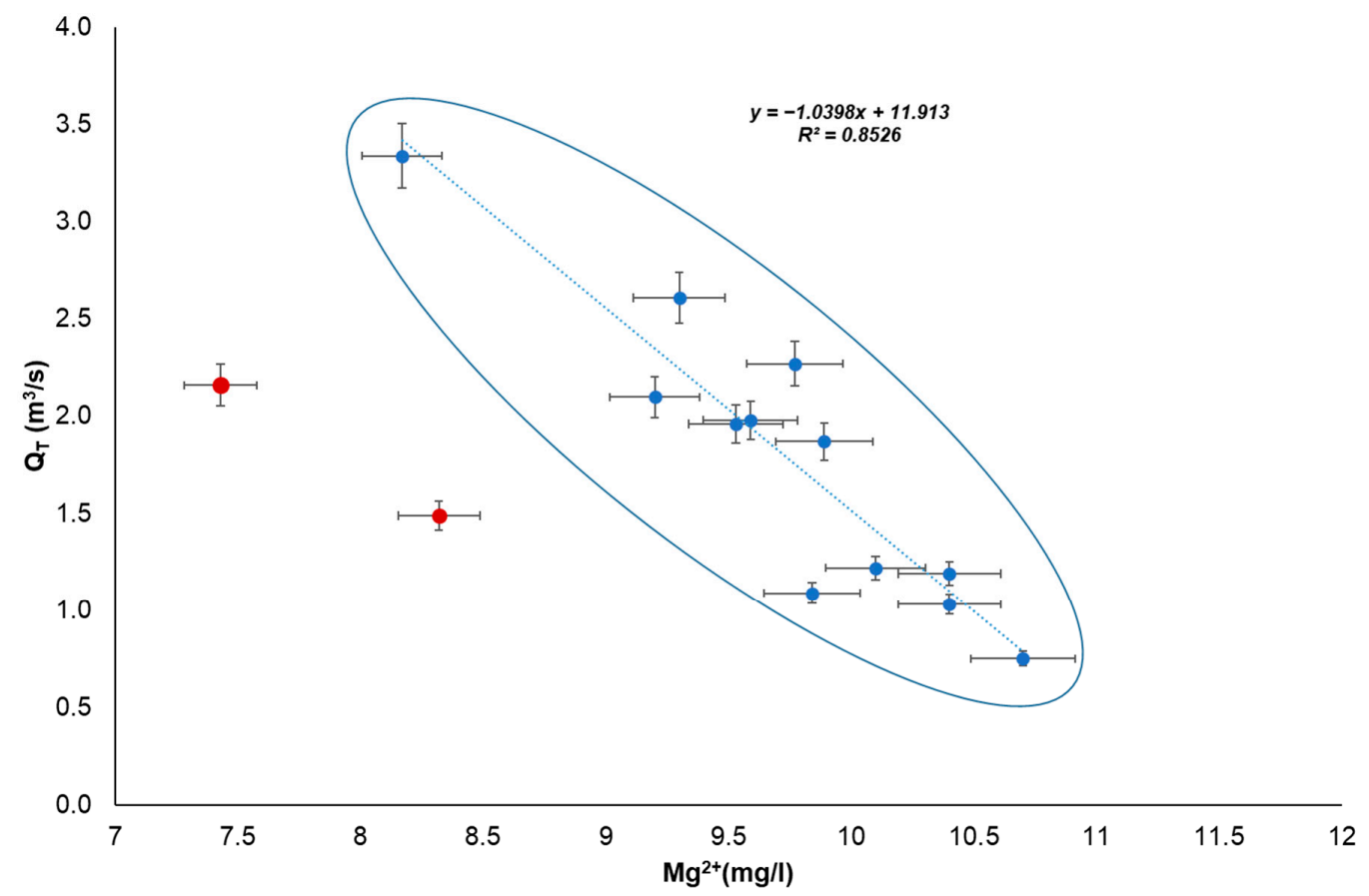

Figure 5. $\mathrm{Mg}^{2+}$ vs. Pertuso Spring total monthly discharges scatter plot with errors related to chemical analyses $( \pm 2 \%)$ and discharge measurements $( \pm 5 \%)$.

Implications are the following:

- $\mathrm{Mg}^{2+}$ content in Pertuso spring water is inversely proportional to total baseflow (BF) discharges $\mathrm{Q}_{\mathrm{T}}$. Twelve samples clearly points out a data cluster around a linear trend with a good correlation $\left(R^{2}=0.85\right)$.

- Maximum concentrations are detected in the same month (November/December), during the minimum seasonal spring flow, except for 2017, when a strong drought event occurs, forcing the water agency to increase the exploitation rate of the spring (Table 3).

- Large deviations from the trend line are related to the activation of discharge overflow (OF) component and the consequent mixing between long residence times groundwa- 
ter and runoff water, quickly flowing through karst conduits. In fact, the marked drop in magnesium content at equal discharges is the result of the mixing.

- Using the mass balance Equation (5) to separate Pertuso Spring BF and OF, it is possible to set up a model which outlines overflow drifts from the baseflow line. Sensitivity analysis starts using typical rainfall $\mathrm{Mg}^{2+}$ contents as $\mathrm{C}_{\mathrm{OF}}$ and a couple of values coming from the linear relationship $\mathrm{C}_{\mathrm{BF}}-\mathrm{Q}_{\mathrm{BF}}$. Based on available literature data, rainfall average $\mathrm{Mg}^{2+}$ content ranges from $0.1-0.3 \mathrm{mg} / \mathrm{L}$ in mountain areas [62-67]. The only free parameter (variable) is $Q_{\mathrm{OF}}$, related to the rainfall event intensity, giving different results of $C_{P}$ (Figure 6).

A simplified representation (inspired by Fiorillo et al. [12]) of the overall model is shown in Figure $6 \mathrm{~A}-\mathrm{C}$, where Pertuso Spring aquifer mechanism is outlined in different phases of the hydrologic year, coupled with water $\mathrm{Mg}^{2+}$ concentrations, sketched with different shades of blue.

$\mathrm{Mg}^{2+}$ concentration allows estimating Pertuso Spring discharges in baseflow conditions and tracing the spring water source, separating baseflow from overflow components in the total amount of discharge data. In particular, a strong rainfall event occurring during the final phase of aquifer depletion immediately implies a drop in $\mathrm{Mg}^{2+}$ content, whose value was enriching due to the longer residence time of groundwater in the carbonate rock.

This is confirmed also by previous studies [53], highlighting the role of antecedent saturation conditions and the karst spring response to different precipitation events. Electrical conductivity, alone, is often not sufficient to describe these kind of processes, whereas water $\mathrm{Mg}^{2+}$ content, together with spring discharges, may be a powerful geochemical tool to evaluate matrix flow (baseflow) rate and distinguish it from the conduit one.
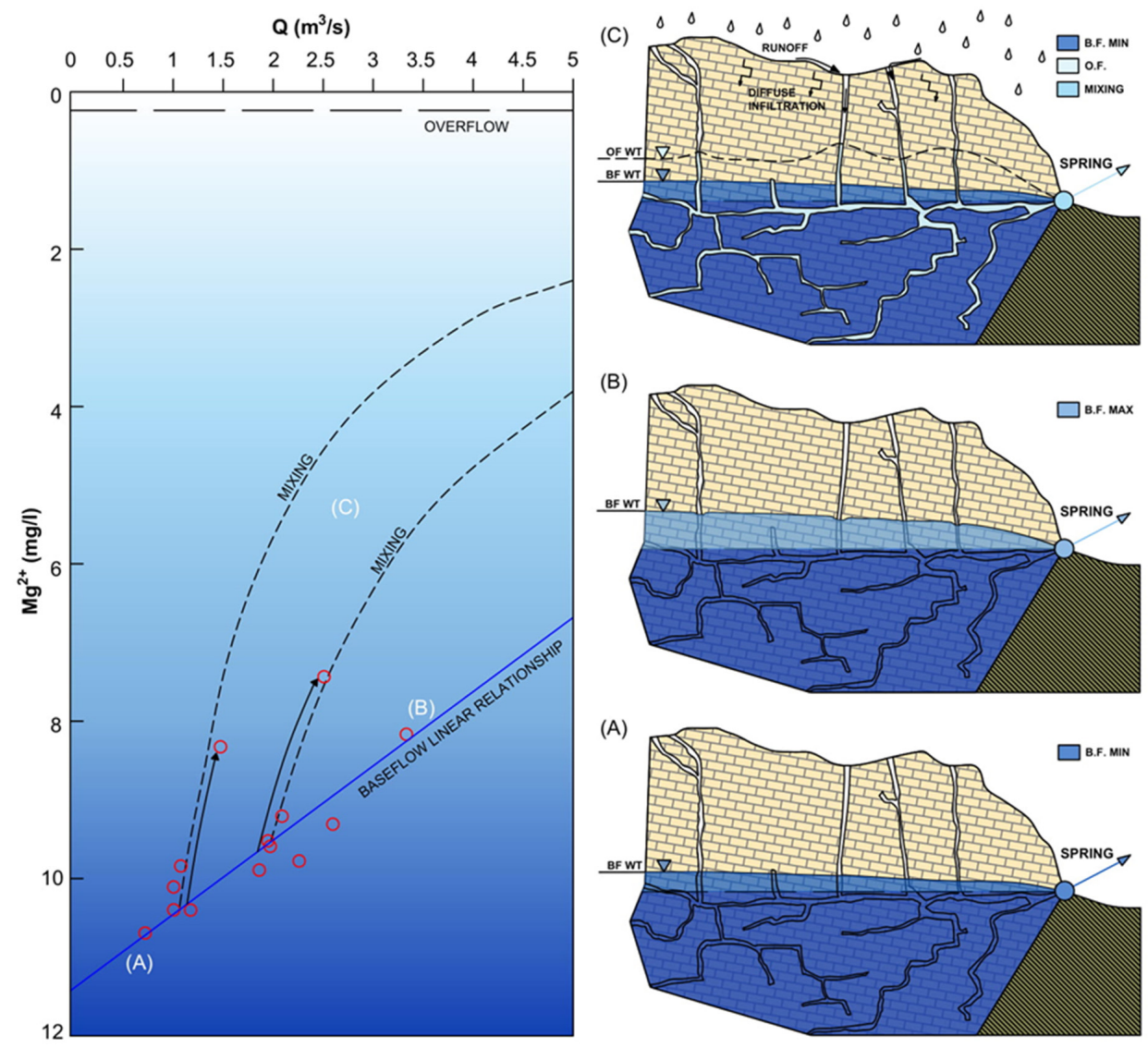

Figure 6. Schematic representation of Pertuso Spring $\mathrm{Mg}^{2+}$ concentrations and karst aquifer mechanism (modified from Fiorillo et al., 2014 [12]): (A)—minimum seasonal base flow (B.F.) discharges correspond to higher $\mathrm{Mg}^{2+}$ contents (dark blue); (B) - maximum seasonal base flow (B.F.) discharges correspond to lower $\mathrm{Mg}^{2+}$ contents (blue); (C)—an intense rainfall event, occurring during seasonal minimum base flow discharges, activates fast overflow (O.F.) coming from conduits network. Groundwater-runoff water mixing leads to an immediate sharp drop in $\mathrm{Mg}^{2+}$ contents (light blue). 


\section{Conclusions}

Chemical mass balance technique has been applied at the confluence of the Pertuso karst spring with the Aniene River (Central Italy), sampling groundwater and surface water from three monitoring points, together with discharge measurements. New collected data confirmed the validity of the proposed model and the conservative behavior of $\mathrm{Mg}^{2+}$ for groundwater related to the Pertuso Spring aquifer, as already exposed in a previous research presented by the authors [47]. Further analysis allowed to obtain a local linear relationship between magnesium concentration and total spring flowrate (including exploitation rate), regardless of the mixing model proposed with the Aniene River. As regards the two samples which fall out of the linear relationship and could have been detected as "outliers", more in-depth data processing and sensitivity analyses revealed that the lowering in magnesium, at equal flowrates, is determined by the appearance of the quick-flow component, less mineralized and related to storm events. Calcium did not show a particular behavior related to the discharge and was not helpful to characterize the hydrogeological dynamic of the Pertuso Spring. Results showed that $\mathrm{Mg}^{2+}$ concentration allows estimating Pertuso Spring discharges in baseflow conditions and tracing the spring water source, separating baseflow from overflow components in the total amount of discharge data. In particular, a strong rainfall event occurring during the final phase of aquifer depletion (winter months) immediately implies a drop in $\mathrm{Mg}^{2+}$ content, whose value was enriching due to the longer residence time of groundwater in the carbonate rock.

Hopefully, future improvements of the research will involve other karst springs of Central Italy with similar hydrodynamics, discharge magnitude, and water geochemistry with the aim of understanding how much this model could be replicated outside the study area.

Meanwhile, the Pertuso Spring will continue to be monitored during planned works referred to the new catchment. In particular, the second phase of the monitoring plan, during which first works are going to start, will consider monthly discharge measurements in order to outline more precisely the complete seasonal recession of the spring aquifer and rapidly detect possible negative impacts of works. This will lead to a further increase of data available to strengthen the proposed model, also involving the recession coefficient in the correlation between spring discharges and magnesium contents. Moreover, a more in-depth study could involve geochemical and isotopic analyses on rainfall samples in the study area and the use of specific probes able to continuously record magnesium concentrations together with the tank water level or spring discharges at a fixed cross-section.

Supplementary Materials: The following are available online at https:/ / www.mdpi.com/2073-444 $1 / 13 / 1 / 93 /$ s1.

Author Contributions: Conceptualization, F.M.D.F. and G.S.; methodology, F.M.D.F.; validation, S.I.; G.G.; investigation, F.M.D.F.; data collecting, S.I and F.M.D.F.; data curation, F.M.D.F. and G.G.; writing—original draft preparation, F.M.D.F.; writing—review and editing, S.I., G.G., and G.S.; supervision, G.S.; project administration, G.S. All authors have read and agreed to the published version of the manuscript.

Funding: This research received no external funding.

Institutional Review Board Statement: Not applicable.

Informed Consent Statement: Not applicable.

Data Availability Statement: The spring data presented in this study are available in supplementary materials [Table S1], whereas precipitation data can be found here: [http:/ / www.idrografico.regione. lazio.it/annali/index.html].

Acknowledgments: The Department of Civil, Building and Environmental Engineering (DICEA) of Sapienza University of Rome supported the research described in this paper. The authors gratefully acknowledge the technical support of ACEA Elabori S.p.A during the monitoring activities.

Conflicts of Interest: The authors declare no conflict of interest. 


\section{References}

1. Hartmann, A.; Goldscheider, N.; Wagener, T.; Lange, J.; Weiler, M. Karst water resources in a changing world. Rev. Geophys. 2013, 2013, 218-242. [CrossRef]

2. Ford, D.; Williams, P. Karst Hydrogeology and Geomorphology. Karst Hydrogeol. Geomorphol. 2013, 1-562. [CrossRef]

3. Stevanović, Z. Karst waters in potable water supply: A global scale overview. Environ. Earth Sci. 2019, 78, 662. [CrossRef]

4. Sappa, G.; Ferranti, F.; Iacurto, S.; De Filippi, F.M. Effects of climate change on groundwater feeding the Mazzoccolo and Capodacqua di Spigno Springs (Central Italy): First quantitative assestments. In Proceedings of the International Multidisciplinary Scientific GeoConference Surveying Geology and Mining Ecology Management, Albena, Bulgaria, 26 August-1 September 2018.

5. Citrini, A.; Camera, C.; Beretta, G. Pietro Nossana Spring (Northern Italy) under Climate Change: Projections of future discharge rates and water availability. Water 2020, 12, 387. [CrossRef]

6. Guo, Q.; Wang, Y.; Ma, T.; Li, L. Variation of karst spring discharge in the recent five decades as an indicator of global climate change: A case study at Shanxi, northern China. Sci. China Ser. D Earth Sci. 2005, 48, 2001-2010. [CrossRef]

7. Kovačič, G.; Petrič, M.; Ravbar, N. Evaluation and quantification of the effects of climate and vegetation cover change on karst water sources: Case studies of two springs in south-western slovenia. Water 2020, 12, 3087. [CrossRef]

8. Fiorillo, F.; Malik, P. Hydraulic behavior of karst aquifers. Water 2019, 11, 1563. [CrossRef]

9. Tamburini, A.; Menichetti, M. Groundwater circulation in fractured and karstic aquifers of the Umbria-Marche Apennine. Water 2020, 12, 1039. [CrossRef]

10. Zhou, W.; Beck, B.F.; Green, T.S. Evaluation of a peat filtration system for treating highway runoff in a karst setting. Environ. Geol. 2003, 44, 187-202. [CrossRef]

11. White, W.B. Karst hydrology: Recent developments and open questions. Eng. Geol. 2002, 65, 85-105. [CrossRef]

12. Fiorillo, F. The Recession of Spring Hydrographs, Focused on Karst Aquifers. Water Resour. Manag. 2014, 28, 1781-1805. [CrossRef]

13. White, W.B. Conceptual Models for Carbonate Aquifers. Ground Water 2012, 50, 180-186. [CrossRef] [PubMed]

14. Sivelle, V.; Labat, D.; Mazzilli, N.; Massei, N.; Jourde, H. Dynamics of the flow exchanges between matrix and conduits in Karstified watersheds at multiple temporal scales. Water 2019, 11, 569. [CrossRef]

15. Bakalowicz, M. Karst groundwater: A challenge for new resources. Hydrogeol. J. 2005, 13, 148-160. [CrossRef]

16. Li, G.; Goldscheider, N.; Field, M.S. Modeling karst spring hydrograph recession based on head drop at sinkholes. J. Hydrol. 2016, 542, 820-827. [CrossRef]

17. Sappa, G.; De Filippi, F.M.; Iacurto, S.; Grelle, G. Evaluation of minimum karst spring discharge using a simple rainfall-input model: The case study of Capodacqua di Spigno Spring (Central Italy). Water 2019, 11, 807. [CrossRef]

18. Diep, T.; Binh, N. Hydrogeochemical characterization and groundwater quality of the dong giao karst aquifer in tam diep, Ninh Binh, Vietnam. Acta Carsologica 2016, 45, 233-242.

19. Hao, Y.; Yeh, T.C.J.; Wang, Y.; Zhao, Y. Analysis of karst aquifer spring flows with a gray system decomposition model. Ground Water 2007, 45, 46-52. [CrossRef]

20. Sappa, G.; Ferranti, F.; De Filippi, F.M. Hydrogeological water budget of the Karst aquifer feeding Pertuso spring (Central Italy). In Proceedings of the International Multidisciplinary Scientific GeoConference Surveying Geology and Mining Ecology Management, SGEM, Albena, Bulgaria, 30 June-6 July 2016.

21. Barfield, B.J.; Felton, G.K.; Stevens, E.W.; McCann, M. A simple model of karst spring flow using modified NRCS procedures. J. Hydrol. 2004, 287, 34-48. [CrossRef]

22. Foster, S.; Hirata, R.; Andreo, B. Le concept de vulnérabilité des aquifères à la pollution: Une aide ou un obstacle au renforcement de leur protection? Hydrogeol. J. 2013, 21, 1389-1392. [CrossRef]

23. Ravbar, N.; Kovacic, G. Vulnerability and protection aspects of some Dinaric karst aquifers: A synthesis. Environ. Earth Sci. 2015, 74, 129-141. [CrossRef]

24. Stroj, A.; Briški, M. Study of Groundwater Flow Properties in a Karst System by Coupled Analysis of Diverse Environmental Tracers and Discharge Dynamics. Water 2020, 12, 2442. [CrossRef]

25. Maas, B.; Peterson, E.W.; Honings, J.; Oberhelman, A.; Oware, P.; Rusthoven, I.; Watson, A. Differentiation of surface water and groundwater in a karst system using anthropogenic signatures. Geoscience 2019, 9, 148. [CrossRef]

26. Uliana, M.M.; Sharp, J.M. Tracing regional flow paths to major springs in Trans-Pecos Texas using geochemical data and geochemical models. Chem. Geol. 2001, 179, 53-72. [CrossRef]

27. Winston, W.E.; Criss, R.E. Dynamic hydrologic and geochemical response in a perennial karst spring. Water Resour. Res. 2004, 40, 1-11. [CrossRef]

28. An, L.; Ren, X.; Hao, Y.; Yeh, T.C.J. Utilizing precipitation and spring discharge data to identify groundwater quick flow belts in a karst spring catchment. J. Hydrometeorol. 2019, 20, 2057-2068. [CrossRef]

29. Raynaud, F.; Borrell-Estupina, V.; Pistre, S.; Van-Exter, S.; Bourgeois, N.; Dezetter, A.; Servat, E. Combining hydraulic model, hydrogeomorphological observations and chemical analyses of surface waters to improve knowledge on karst flash floods genesis. Proc. Int. Assoc. Hydrol. Sci. 2015, 369, 55-60. [CrossRef]

30. Imes, J.L.; Plummer, L.; Kleeschulte, M.J.; Schumacher, J.G. Recharge Area, Base-Flow and Quick-Flow Discharge Rates and Ages, and General Water Quality of Big Spring in Carter County, Missouri, 2000-2004. Sci. Investig. Report. USA Geol. Surv. 2007, 80. [CrossRef] 
31. Iacurto, S.; Grelle, G.; Filippi, F.M.D.; Sappa, G. Karst spring recharge areas and discharge relationship by oxygen-18 and deuterium isotopes analyses: A case study in southern latium region, Italy. Appl. Sci. 2020, 10, 1882. [CrossRef]

32. Lange, J.; Greenbaum, N.; Husary, S.; Timmer, J.; Leibundgut, C.; Schick, A.P. Tracers for runoff generation studies in a Mediterranean region: Comparison of different scales. Proc. Int. Assoc. Hydrol. Sci. 2003, 117-123.

33. Stauffer, R.E. Use of Solute Tracers Released by Weathering To Estimate Groundwater Inflow to Seepage Lakes. Environ. Sci. Technol. 1985, 19, 405-411. [CrossRef] [PubMed]

34. Lauber, U.; Goldscheider, N. Utilisation des traceurs naturels et artificiels pour estimer la distribution des temps de transit et les systèmes d'écoulement dans un système karstique alpin d'altitude (Montagnes Wetterstein, Allemagne). Hydrogeol. J. 2014, 22, 1807-1824. [CrossRef]

35. Aquilanti, L.; Clementi, F.; Nanni, T.; Palpacelli, S.; Tazioli, A.; Vivalda, P.M. DNA and fluorescein tracer tests to study the recharge, groundwater flowpath and hydraulic contact of aquifers in the Umbria-Marche limestone ridge (central Apennines, Italy). Environ. Earth Sci. 2016, 75, 1-17. [CrossRef]

36. Nanni, T.; Vivalda, P.M.; Palpacelli, S.; Marcellini, M.; Tazioli, A. Groundwater circulation and earthquake-related changes in hydrogeological karst environments: A case study of the Sibillini Mountains (central Italy) involving artificial tracers. Hydrogeol. J. 2020. [CrossRef]

37. Vesper, D.J.; White, W.B. Storm pulse chemographs of saturation index and carbon dioxide pressure: Implications for shifting recharge sources during storm events in the karst aquifer at Fort Campbell, Kentucky/Tennessee, USA. Hydrogeol. J. 2004, 12, 135-143. [CrossRef]

38. Banzato, C.; De Waele, J.; Fiorucci, A.; Vigna, B.; Torino, P.; Duca, C. Study of springs and karst aquifers by monitoring and geochemical analysis. In Proceedings of the 9th Conference om Limestone Hydrogeol., Besançon, France, 1-3 September 2011; pp. $45-48$.

39. Vigna, B. Acquisizione ed interpretazione dei dati di monitoraggio delle sorgenti. Geoing. Ambient. Min. 2014, $143,43-58$.

40. Okello, A.M.L.S.; Uhlenbrook, S.; Jewitt, G.P.W.; Masih, I.; Riddell, E.S.; Van Der Zaag, P. Hydrograph separation using tracers and digital filters to quantify runoff components in a semi-arid mesoscale catchment. Hydrol. Process. 2018, 32, 1334-1350. [CrossRef]

41. Zeng, S.; Liu, Z.; Goldscheider, N.; Frank, S.; Goeppert, N.; Kaufmann, G. Comparisons on the effects of temperature, runoff, and land-cover on carbonate weathering in different karst catchments: Insights into the future global carbon cycle Comparisons on the effects of temperature, runoff, and land-cover on carbonate weath. Hydrogeol. J. 2020, 1-15. [CrossRef]

42. Ravbar, N.; Barberá, J.A.; Petrič, M.; Kogovšek, J.; Andreo, B. The study of hydrodynamic behaviour of a complex karst system under low-flow conditions using natural and artificial tracers (the catchment of the Unica River, SW Slovenia). Environ. Earth Sci. 2012, 65, 2259-2272. [CrossRef]

43. Ravbar, N.; Engelhardt, I.; Goldscheider, N. Anomalous behaviour of specific electrical conductivity at a karst spring induced by variable catchment boundaries: The case of the Podstenjšek spring, Slovenia. Hydrol. Process. 2011, 25, 2130-2140. [CrossRef]

44. Guo, Y.; Qin, D.; Li, L.; Sun, J.; Li, F.; Huang, J. A complicated karst spring system: Identified by karst springs using water level, hydrogeochemical, and isotopic data in Jinan, China. Water 2019, 11, 947. [CrossRef]

45. Cozma, A.I.; Baciu, C.; Moldovan, M.; Pop, I.-C. Using Natural Tracers to Track the Groundwater Flow in a Mining Area. Procedia Environ. Sci. 2016, 32, 211-220. [CrossRef]

46. Rovan, L.; Lojen, S.; Zuliani, T.; Kanduč, T.; Petrič, M.; Horvat, B.; Rusjan, S.; Štrok, M. Comparison of uranium isotopes and classical geochemical tracers in Karst Aquifer of Ljubljanica River catchment (Slovenia). Water 2020, 12, 2064. [CrossRef]

47. Sappa, G.; Ferranti, F.; De Filippi, F.M.; Cardillo, G. $\mathrm{Mg}^{2+}$-based method for the Pertuso spring discharge evaluation. Water 2017, 9, 67. [CrossRef]

48. Chapman, P.J.; Reynolds, B.; Wheater, H.S. Sources and controls of calcium and magnesium in storm runoff: The role of groundwater and ion exchange reactions along water flowpaths. Hydrol. Earth Syst. Sci. 1997, 1, 671-685. [CrossRef]

49. Hannigan, R.; Bickford, N. Hydrochemical variations in a Spring-Fed River, Spring River, Arkansas. Environ. Geosci. 2003, 10, 167-188. [CrossRef]

50. Kissel, M.; Schmalz, B. Comparison of baseflow separation methods in the german low mountain range. Water 2020, $12,1740$. [CrossRef]

51. Wang, F.; Chen, H.; Lian, J.; Fu, Z.; Nie, Y. Seasonal Recharge of Spring and Stream Waters in a Karst Catchment Revealed by Isotopic and Hydrochemical Analyses. J. Hydrol. 2020, 591, 125595. [CrossRef]

52. Kiewiet, L.; Van Meerveld, I.; Stähli, M.; Seibert, J. Do stream water solute concentrations reflect when connectivity occurs in a small, pre-Alpine headwater catchment? Hydrol. Earth Syst. Sci. 2020, 24, 3381-3398. [CrossRef]

53. Toran, L.; Reisch, C.E. Using stormwater hysteresis to characterize karst spring discharge. Groundwater 2013, 51, 575-587. [CrossRef]

54. Bencala, K.E.; McKnight, D.M.; Zellweger, G.W. Evaluation of Natural Tracers in an Acidic and Metal-Rich Stream. Water Resour. Res. 1987, 23, 827-836. [CrossRef]

55. Schemel, L.E.; Cox, M.H.; Runkel, R.L.; Kimball, B.A. Multiple injected and natural conservative tracers quantify mixing in a stream confluence affected by acid mine drainage near Silverton, Colorado. Hydrol. Process. 2006, 20, 2727-2743. [CrossRef]

56. D'Orefice, M.; Falcetti, S.; Moretti, P.; Pantaloni, M.; Pichezzi, R.M.; Scalise, A.R. Un territorio da (ri) scoprire: L'alta Valle del fiume Aniene-The upper Aniene river Valley: A land to (re)discover. Mem. Descr. Carta Geol. d'It. 2014, 102, $101-117$. 
57. Carrara, C.; Branca, M.; Cerone, E.P.; Verrubbi, V.; Voltaggio, M. The calcareous tufa deposits of the Aniene Valley between Vallepietra and Mandela-Vicovaro (Latium, Central Italy). Alp. Mediterr. Quat. 2006, 19, 19-44.

58. Fabbi, S. Geology of the eastern slopes of the Simbruini Mts. Between Verrecchie and Capistrello (Central Apennines-Abruzzo, Italy). J. Maps 2018, 14, 435-446. [CrossRef]

59. Cavinato, G.P.; Corrado, S.; Sirna, M. Dati preliminari sull'assetto geologico strutturale del settore sud-occidentale della struttura simbruino-ernica. Studi Geol. Camerti. 1991, 11, 33-42.

60. Magdalene, S.; Elias, J.E.; Damstra, R.; Vandermeulen, D.D.; North, S.; Service, N.P.; Inventory, G.L.; Network, M.; Elias, J.E.; Damstra, R.; et al. Standard Operating Procedure \#10: Flow Measurement. In Monitoring Protocol for Wadeable Streams of the Great Lakes Network, version 1.0. Natural Resource ReportNPS/GLKN/NRR—2017/1567; National Park Service: Fort Collins, CO, USA, 2017.

61. International Standard-ISO 748. Measurement of Liquid Flow in Open Channels Using Current-Meters or Floats. Geneve 2007. Available online: https:/ /www.iso.org/standard/37573.html (accessed on 3 December 2020).

62. Rantz, S.E. Measurement and Computation of Streamflow: Volume 1. In Measurement of Stage and Discharge; U.S. Government Printing Office: Washington, DC, USA, 1982.

63. Pearson, F.J. Chemical Composition of Atmospheric Precipitation in the Northeastern United States; U.S. Government Printing Office: Washington, DC, USA, 1983.

64. Grimshaw, H.J.; Dolske, D.A. Rainfall concentrations and wet atmospheric deposition of phosphorus and other constituents in Florida, U.S.A. Water. Air. Soil Pollut. 2002, 137, 117-140. [CrossRef]

65. Sapek, B. Calcium and Magnesium in atmospheric precipitation, groundwater and the soil solution in long-term meadow experiments. J. Elem. 2014, 19, 191-208. [CrossRef]

66. Aiuppa, A.; Bonfanti, P.; D'Alessandro, W. Rainwater chemistry at Mt. Etna (Italy): Natural and anthropogenic sources of major ions. J. Atmos. Chem. 2003, 46, 89-102. [CrossRef]

67. Global Atmosphere Watch, Quality Assurance/Science Activity Centre-Americas. Data retrieved from QA/SAC-Americas. Available online: https:/ / qasac-americas.org/ (accessed on 3 November 2020). 